\title{
Determining the risk factors associated with delayed sputum conversion at the end of the intensive phase among tuberculosis patients
}

Zohra Bhatti, ${ }^{1}$ Amer Hayat Khan, ${ }^{1}$ Syed Azhar Syed Sulaiman, ${ }^{1}$ Madeeha Laghari ${ }^{1}$ and Irfhan Ali Bin Hyder Ali ${ }^{2}$

'Department of Clinical Pharmacy, School of Pharmaceutical Sciences Universiti Sains Malaysia, Penang, Malaysia. (Correspondence to: Zohra Bhatti: zohrabhatti@gmail.com). ${ }^{2}$ Respiratory Department, Hospital Palau Pinang, Penang, Malaysia.

\begin{abstract}
Background: In pulmonary tuberculosis (PTB), the sputum conversion rate at 2 months is frequently used to evaluate treatment outcomes and effectiveness of a TB control programme.

Aims: The study aimed to estimate the rate of delayed sputum conversion and explore its predicting factors at the end of the intensive phase among smear-positive PTB (PTB +ve) patients.

Methods: A 3-year retrospective study was conducted in the government hospital in Pulau Pinang from 2016 to 2018. During the study, a standardized, data collection form was used to collect data from the patient record. Patients aged over 18 years were recruited. Multivariable logistic regression analysis was used to identify significant independent variables associated with delayed sputum conversion.

Results: A total 1128 of PTB patients were recorded visiting the TB clinic, 736 (65.2\%) were diagnosed as PTB +ve; of these, 606 (82.3\%) PTB + ve had a record of sputum conversion at the end of the intensive phase. Age $\geq 50$ years, blue-collar jobs, smoking, heavy bacillary load, relapsed and treatment interrupted were significantly $(P<0.05)$ associated with delayed sputum conversion. Delayed sputum conversion rate at the end of the intensive phase was $30.5 \%$.

Conclusion: The rate of sputum smear conversion in the intensive phase of treatment was independently associated with high sputum smear grading at diagnosis, relapsed and treatment interrupted categories, old age and blue-collar occupations.

Keywords: delayed conversion rate, tuberculosis, sputum, bacillary count, treatment outcomes

Citation: Bhatti Z; Khan AH; Sulaiman SAS; Laghari M; Ali IABH. Determining the risk factors associated with delayed sputum conversion at the end of the intensive phase among tuberculosis patients. East Mediterr Health J. 2021;27(8):755-763. https://doi.org/10.26719/2021.27.8.755

Received: 01/06/20; accepted: 20/12/20

Copyright (c) World Health Organization (WHO) 2021. Open Access. Some rights reserved. This work is available under the CC BY-NC-SA 3.0 IGO license (https://creativecommons.org/licenses/by-nc-sa/3.0/igo).
\end{abstract}

\section{Introduction}

Sputum smear conversion from positive to negative is one of the useful indicators to determine the efficacy of anti-tuberculosis treatment and essential in the clinical evaluation of patients with smear-positive pulmonary tuberculosis (PTB +ve). Delayed sputum smear conversion after 2 months of intensive phase has been associated with possible continuity of infectiousness, higher risk of treatment default, treatment failure, development of drug-resistant tuberculosis (TB) and the potential increase in TB mortality (1). The sputum smear conversion rate is defined as the percentage of registered smear positive TB cases in a given period converting to smear negative after 2 months of anti-tuberculosis treatment $(2,3)$. The World Health Organization (WHO) recommends an annual assessment of treatment outcomes to identify risk and create policies to improve the efficiency of national TB control plans.

The most effective way of preventing the transmission of $\mathrm{TB}$ is the identification and cure of infectious PTB + ve patients (4). Active PTB and PTB +ve with a heavy bacillary load are the primary sources of infection
(5) besides having the capacity of transmitting TB to 15 people a year (6). According to $\mathrm{WHO}$, all PTB + ve patients should be evaluated for bacteriological status after the intensive phase to determine treatment outcomes (7).

In Malaysia, TB is a significant health problem with the current incidence rate of 92 per 100000 and an annual mortality rate of 4.1 per 100000 population (7). Malaysia is a multi-racial country with 3 different main ethnic groups: $67.4 \%$ Malay, $24.6 \%$ Chinese and $7.3 \%$ Indian, $0.7 \%$ other (8). The TB control programme encompasses various indicators to examine TB prevention and control. For the past 5 years, the sputum conversion rate was reported in the range of $60-80 \%$ and the treatment success rate $75-78 \%$, despite the $85 \%$ TB treatment success rate defined by the WHO global target $(1,9)$. Therefore, evaluating risk factors for delayed sputum conversion is necessary for health care providers and policy-makers to ensure the correct measures to avoid unfavourable outcomes. Factors affecting sputum smear conversion have previously been studied in Malaysia $(1,10-12)$ and some research has discussed treatment outcomes of TB therapy (9). The present study is different from previous 
studies (conducted in Malaysia) in evaluating the trends of PTB over the past 3 years, estimating the rate of delayed sputum conversion, and exploring its predicting factors together with the association of delayed sputum conversion rate with treatment outcomes among PTB +ve patients. Hence, the objective of the current study is to determine the sputum conversion rate and identify the risk factors of delayed sputum conversion at the end of the intensive phase of treatment.

\section{Methods}

\section{Study design and settings}

We conducted a retrospective study of PTB +ve patients registered from 2016 to 2018 in Pulau Pinang hospital, a tertiary care public hospital with 1017 beds situated in northern Malaysia. Tuberculosis-related information was indexed and analysed using hospital case records of patients over 18 years old with all comorbid conditions.

\section{Data collection}

A data collection form was specially designed for this study and all data information was transferred on it from the patient record file. The main variables of data tool were sociodemographics, clinical presentation of $\mathrm{TB}$, bacteriological examination during management, patient's previous medical record, duration of therapy, and treatment outcomes. We retrospectively reviewed all PTB +ve patients who visited or were transferred in and diagnosed with confirmed bacteriological and radiological evidence of PTB.

\section{Diagnosis}

Initial TB diagnosis is based on bacteriological results of sputum smear examination of acid-fast bacilli (AFB), (Xpert MTB/RIF assay, Cepheid, New Jersey), sputum culture, chest X-ray, and histopathology examination of any tissue in the case of extra-pulmonary TB. Sputum samples are collected from each patient over 2 or 3 consecutive days and sent to a local laboratory for microscopic examination. For PTB +ve patients, the Xpert MTB/RIF assay is used as an add-on diagnostic to detect rifampin-resistant strains and bronchoalveolar lavage for patients who are unable to expectorate sputum. Lab- oratory tests, including full blood count, liver function test, blood glucose level, human immunodeficiency virus (HIV) screening and erythrocyte sedimentation rate are carried out on diagnosis. Posteroanterior chest X-rays are performed for all patients before treatment, at the end of the intensive phase and at the end of TB treatment. The severity of disease is measured by the number of lobes and the presence of cavitation (2).

$\mathrm{PTB}+\mathrm{ve}$ patients with at least 2 initial sputum smear examinations positive for $\mathrm{AFB}$ or one sputum smear examination positive with radiological abnormality or sputum culture positive for mycobacterium TB were receiving a standard 6-month course of antituberculosis treatment. First, 2 months of intensive treatment have fixed-dose combination tablets containing rifampicin (600 mg), isoniazid (300 mg), pyrazinamide (1500 mg), and ethambutol (1200 mg). This is followed by a 4-month continuous phase with a daily dose of isoniazid and rifampicin. Patients who remained smear positive even after the intensive phase or who had cavitary disease received more extended treatment with the first-line anti-tuberculosis treatment continuing till the end of the 3rd month. Treatment outcomes in Malaysian guidelines are defined as per WHO recommendations (Table 1) (13).

Cured and treatment complete were represented as TB treatment success; treatment failure, died and transferred were classified as unsuccessful treatment outcome. Sputum grading is categorized according to the current number of AFB at the time of sputum smear microscopy after scanning using the Ziehl-Neelsen technique. The WHO recommends 4 grades of $\mathrm{PTB}+\mathrm{ve}$ cases: scanty (1-9 AFB/100 fields), $1+$ (10-99 AFB/100 fields), $2+$ (1-9 AFB/50 fields), and $3+$ (> $10 \mathrm{AFB} /$ field in at least 20 fields) (14).

\section{Data analysis}

Data were analysed using SPSS. The Pearson chi-squared test was used for categorical variables to make a comparison of proportions. Multivariable logistic regression analysis was used to examine the possible association between a dependent variable and independent risk factors for delayed bacteriological conversion at the end to the intensive phase of TB management. $P$-value $<0.05$ was considered statistically significant. The adjusted odds

\begin{tabular}{ll}
\hline Table 1 Definitions for treatment outcomes \\
$\begin{array}{ll}\text { Outcome } & \text { Definition } \\
\text { Cure } & \begin{array}{l}\text { Patient who was sputum smear-positive at the start of treatment and has become smear-negative at the end of } \\
\text { treatment and on at least one previous occasion }\end{array} \\
\text { Treatment complete } & \begin{array}{l}\text { Patient who was smear-negative initially and completed his treatment but without evidence of the negative } \\
\text { bacteriological status and on at least one previous occasion }\end{array} \\
\text { Default } & \begin{array}{l}\text { Patient who had interrupted his treatment for consecutive } 2 \text { months or more after getting registered } \\
\text { Treatment failure }\end{array} \\
& \begin{array}{l}\text { Patient whose sputum smear or culture is positive at } 5 \text { months or later during treatment. Also included in this } \\
\text { whether they are smear negative or positive }\end{array} \\
\text { Died } & \begin{array}{l}\text { Patient who died during TB treatment due to TB or any disease } \\
\text { Pransferred out }\end{array}\end{array}$ \\
\hline Adapted from = Treatment of tuberculosis: guidelines (14).
\end{tabular}


ratio (AOR), 95\% confidence interval (CI), beta, standard error and $P$-value were reported for each predictor. Sex, age, weight, occupation, ethnicity, smoking, intravenous drug use, bacillary load, patient's registration category, treatment outcomes, chest X-ray lesion, adverse drug reactions and comorbidities were analysed.

\section{Ethical approval}

The study was approved by the Medical Research Ethics Committee, Ministry of Health, Malaysia (Registration ID: NMRR-18-1145-40397; MREC reference: dim. KKM/ NIHSEC P18-1198 (6).

\section{Results}

Figure 1 represents the total number of PTB patients who visited the TB clinic. Of 1128 patients, 736 (65.2\%) were diagnosed as PTB +ve but $606(82.3 \%)$ of these had a record of sputum conversion at the end of the intensive phase.

Initially the number of PTB +ve patients was 230 in 2016, which increased slightly to 270 in 2018 (Figure 2). Conversely, a higher drop-off rate was observed in delayed sputum converted PTB + ve patients from 93 cases in 2016 to 32 cases in 2018.

The sociodemographic profile of sputum smear converted and delayed sputum converted patients at the end of intensive phase is described in Table 2. Of the 606 PTB +ve patients, 445 (73.4\%) were males, $268(44.2 \%)$ were aged $\geq 50$ years and $299(49.3 \%)$ were Chinese. Of these 606 patients included in the analysis with record of sputum smear conversion after the intensive phase of TB treatment, $421(69.5 \%)$ converted their sputum while
$185(30.5 \%)$ failed to become sputum negative. Of the delayed sputum conversion patients, $152(82.2 \%)$ became sputum negative in the 3rd month of treatment and the remaining patients eventually recovered in the first week of the 4th month.

Table 3 presents a full description of the clinical characteristics of PTB +ve patients. Pretreatment examination microscopy results for PTB +ve patients who were analysed at the end of the intensive phase include the highest number of patients with $3+$ grading (30.4\%) and the lowest number with grading $4+$. The treatment success rate in this study was $69.1 \%$. The comorbidities included HIV 36 (5.9\%), diabetes 107 (17.6\%), hepatitis $21(3.4 \%)$ and other comorbidities 45 (7.4\%). Other comorbidities were: hypertension 14 (31.1\%), dyslipidaemia $5(11.1 \%)$, chronic obstructive pulmonary disease $15(33.3 \%)$, cancer $4(8.8 \%)$ and fractures $7(15.5 \%)$.

The factors found to be statistically significantly associated with delayed sputum conversion treatment in multivariable logistic regression analysis are shown in Table 4. They include treatment failure (AOR 4.7; 95\% CI: 1.6-12.6), relapsed PTB patients (AOR 4.6; 95\% CI: 2.7-7.9) and high bacillary load with sputum grading $2+$ and $3+$ (AOR 2.4; 95\% CI: 1.5-4.6) and (AOR 2.6; 95\% CI: 1.7-4.2) respectively.

\section{Discussion}

Our study focused on describing the delayed sputum conversion rate among PTB +ve patients treated in Pulau Pinang hospital, Malaysia from 2016 to 2018. In the present study, an increase in PTB + ve cases was noted during

\section{Figure 1 Algorithm showing the distribution of tuberculosis (TB) patients and pulmonary tuberculosis (PTB) positivity}

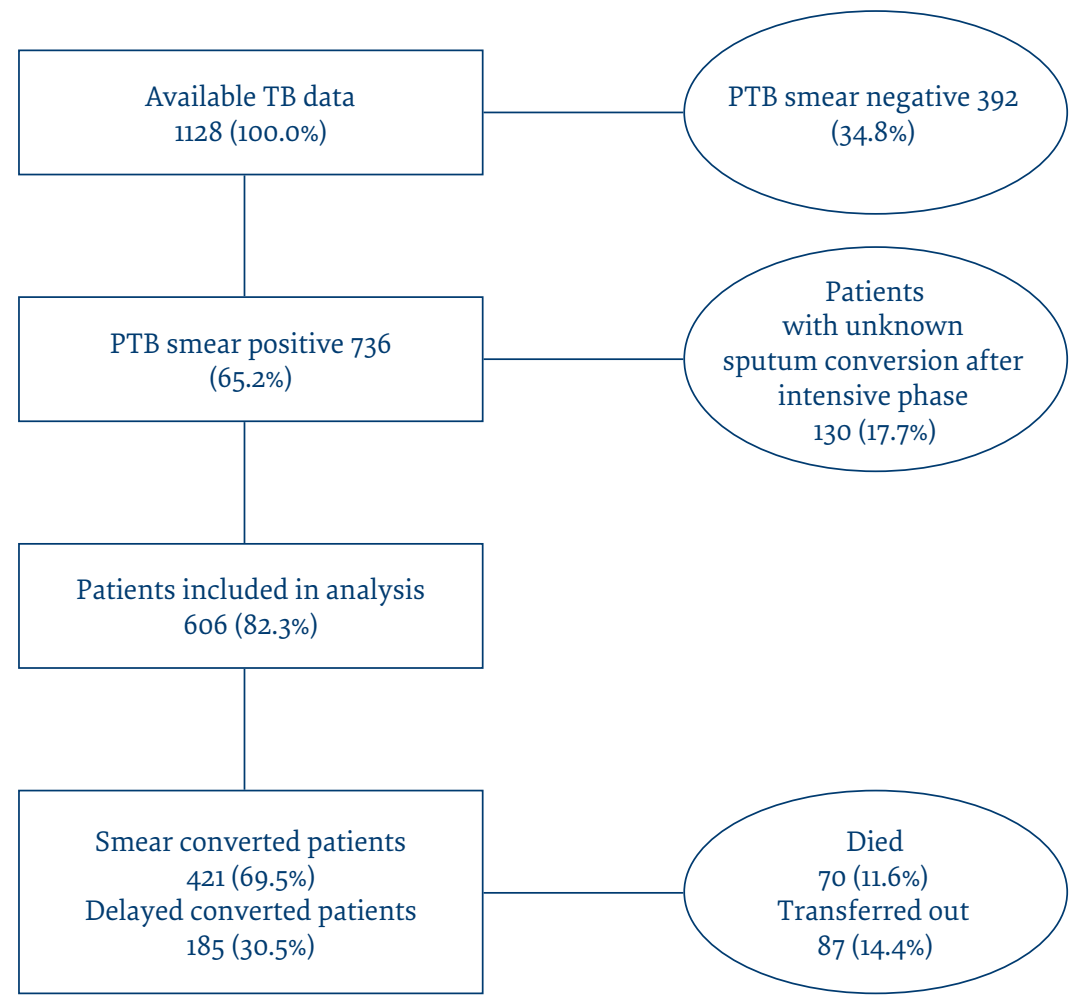




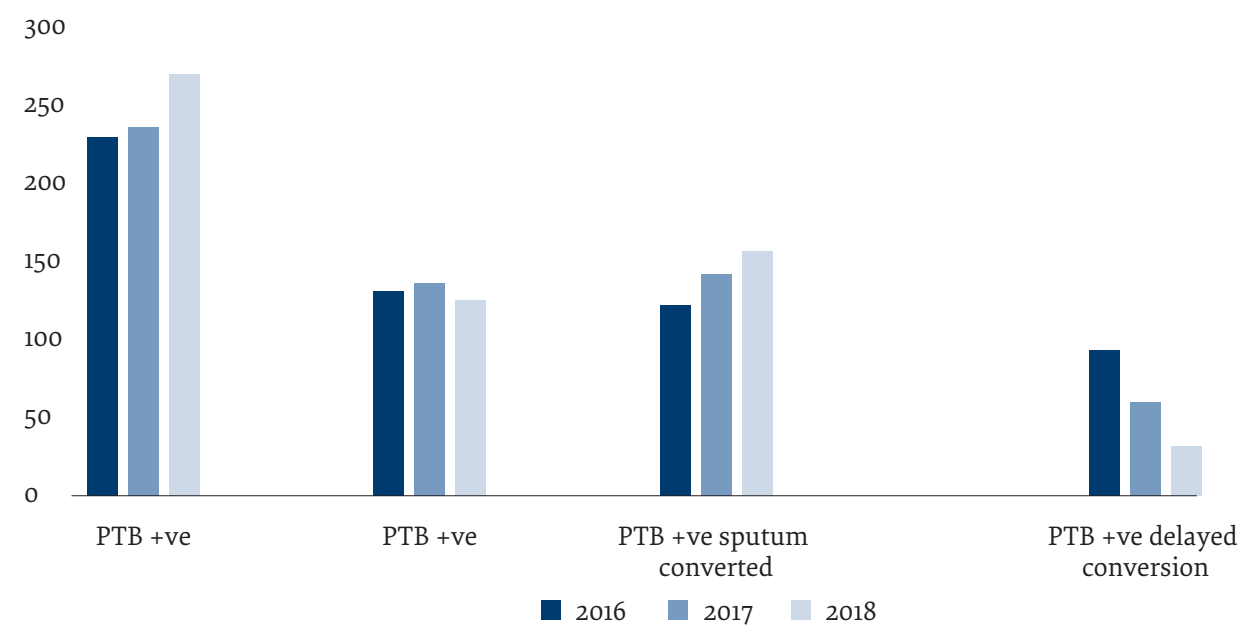

the study period and these findings need great attention from the health care perspective. Furthermore, essential steps are required to limit this increase in infectiousness and overall number of TB cases at the study site as well as in the whole of Malaysia.

We evaluated 606 PTB +ve patients to study delayed sputum conversion at the end of the intensive phase of treatment. Approximately $70 \%$ had converted their sputum status in time while $30 \%$ failed to achieve standard sputum conversion at the end of the intensive phase. Previous research in Malaysia also reported sputum conversion rates in the range $55-75 \%(9,10,15)$. In previous research in Rwanda and Lithuania, the delayed sputum conversion rate has been reported at around 25\% $(3,16)$. Our findings also verified that the conversion to negative sputum and decrease in PTB infection during treatment does not occur rapidly in all patients $(4,5)$. Our study findings are contrary to the view that after 2 months of standard treatment patients become noninfectious.

Delayed sputum conversion might many a number of explanations: first and foremost is the presence of viable bacteria detected by microscopic examination. In resource-limited TB endemic settings, cure is declared through sputum smear examination for AFB without performing a culture, which leads to erroneous treatment outcomes as viable bacteria may be missed due to the low sensitivity of the direct smear method. Therefore, culture may be the best technique to evaluate the viability of Mycobacterium tuberculosis $(4,17)$. Other potential causes for delayed sputum conversion might be non-compliance of patients, poor implementation of the DOT therapy, inappropriate dose calculation, probability of drug resistance, pretreatment high bacillary load (18) and the high proportion of relapse and treatment failure cases (19). In our study, age $\geq 50$ years, blue-collar jobs, smoking, heavy bacillary load and relapsed TB patients showed a significant association between delayed sputum conversions.
In line with current results, many studies stated that older age $\geq 50$ years was an independent risk for of delayed sputum conversion in TB patients due to the elevated incidence of physical disabilities among such patients, the ineffective bacilli clearance because of fragile immunity, and delay in pursuing diagnosis and treatment $(6,14,19-21)$. Blue-collar work was another contributing factor for delayed sputum conversion at the end of the intensive phase. Patients with manual jobs generally have low incomes, and thus possibly poor access to health facilities, a poor lifestyle, low education level, lower motivation and less seriousness regarding illness and malnutrition, which lead to reactivation of $\mathrm{TB}$ and poor treatment outcomes (22).

Smoking as an independent predictor of delayed sputum smear conversion had been supported by other studies as well $(23,24)$. Tobacco smoke suppresses the antigen expression to develop a specific immune response and stimulates the alveolar macrophages for inflammatory activity, thus causing T-cell anergy $(25,26)$. Hence, this weak immunity pattern in the lungs of smokers leads to delayed bacillary clearance.

With regard to bacillary load, our findings identified it as a potential risk for delayed sputum conversion at the end of the intensive phase. Patients with a high sputum grading were more likely to be smear positive in the intensive phase as compared to patients having a lower sputum grading (27). Other more extensive retrospective studies corroborate our findings $(28,29)$. Singla et al. reported 6 times greater probability of delayed sputum conversion in patients with heavy bacillary load at the pretreatment stage (29).

The observed treatment success rate was $69.1 \%$ with respect to sputum conversion, i.e. less than the target success rate $(85 \%)$ for PTB +ve patients. The treatment success rate in Malaysia has been documented in a research report, consistent with our findings, showing a declining pattern in the success rate (9). This decline is linked with inconsistent sputum monitoring, relying 


\begin{tabular}{|c|c|c|c|}
\hline Characteristic & $\begin{array}{l}\text { Converted } \\
(n=421)\end{array}$ & $\begin{array}{l}\text { Delayed converted } \\
\qquad(n=185)\end{array}$ & $\begin{array}{c}\text { Total } \\
(n=606)\end{array}$ \\
\hline & No. (\%) & No. (\%) & No. (\%) \\
\hline \multicolumn{4}{|l|}{ Sex } \\
\hline Male & 307 (68.9) & $138(31.0)$ & $445(73.4)$ \\
\hline Female & $114(70.8)$ & $47(29.1)$ & $161(26.5)$ \\
\hline \multicolumn{4}{|l|}{ Age (years) } \\
\hline $18-35$ & $131(75.3)$ & $43(24.7)$ & $174(28.7)$ \\
\hline $36-50$ & $123(75.0)$ & $41(25.0)$ & $164(27.1)$ \\
\hline$\geq 50$ & $167(62.3)$ & $101(37.7)$ & $268(44.2)$ \\
\hline \multicolumn{4}{|l|}{ Weight (kg) } \\
\hline $30-45$ & $157(83.0)$ & $32(16.9)$ & $189(31.2)$ \\
\hline $46-60$ & $79(61.7)$ & $49(38.2)$ & $128(21.1)$ \\
\hline $61-75$ & $133(65.5)$ & $70(34.4)$ & $203(33.5)$ \\
\hline$>75$ & $52(60.5)$ & $34(39.5)$ & $86(14.2)$ \\
\hline \multicolumn{4}{|l|}{ Occupation } \\
\hline White-collar & $18(69.2)$ & $8(30.8)$ & $26(4.3)$ \\
\hline Blue-collar & $133(60.4)$ & $87(39.5)$ & $220(36.3)$ \\
\hline Unknown status & $270(75.0)$ & $90(25.0)$ & $360(59.4)$ \\
\hline \multicolumn{4}{|l|}{ Ethnicity } \\
\hline Malay & $145(74.7)$ & $49(26.4)$ & $194(32.0)$ \\
\hline Chinese & $200(66.9)$ & $99(33.1)$ & 299 (49.3) \\
\hline Indian & $44(67.7)$ & $21(32.3)$ & $65(10.7)$ \\
\hline Foreign & $32(66.7)$ & $16(33.3)$ & $48(7.9)$ \\
\hline \multicolumn{4}{|l|}{ Smoking habit } \\
\hline Smoker & $127(59.1)$ & 88 (40.9) & $215(35.5)$ \\
\hline Non-smoker & $275(76.2)$ & $86(23.8)$ & $361(59.6)$ \\
\hline Ex-smoker & $19(63.4)$ & $11(36.6)$ & $30(5.0)$ \\
\hline \multicolumn{4}{|l|}{ Intravenous drug use } \\
\hline Yes & $37(72.5)$ & $14(27.4)$ & $51(8.4)$ \\
\hline No & $377(69.4)$ & $166(30.5)$ & $543(89.6)$ \\
\hline Ex-user & $7(58.3)$ & $5(41.6)$ & $12(2.0)$ \\
\hline
\end{tabular}

on sputum microscopy not considering sputum culture, frail treatment scrutinization, and the relapse of TB symptoms after sputum conversion and the substantial proportion of patients with unevaluated status or being transferred out. In our study, a large number of PTB patients were reported as treatment interrupted and transferred out, and this may illustrate the issues faced by migrant workers, especially those with poor or no legal documents.

Our study had some limitations. It was conducted in a state-level tertiary care hospital, but a non-subsequent proportion of patients, retrospective study design, inaccessibility of subjective evaluation of certain clinical features and lack of data indicate that the current findings do not depict the overall delayed sputum conversion rate and TB treatment success rate for Malaysia. Therefore, our findings should be applied with caution in assessing the general TB treatment success rate in Malaysia.

\section{Conclusion}

To conclude, this study demonstrated that PTB +ve patients aged $\geq 50$ years and those with blue-collar jobs (manual labour), smoking, heavy bacillary load and the relapsed and treatment defaulter category of PTB were significant independent predictors of delayed sputum conversion at the end of the intensive phase of treatment. Sputum positivity at 2 months is also associated with poor treatment outcomes. These potential risk factors examined may aid in recognizing patients who may have delayed sputum conversion and may result in poorer treatment outcomes. 


\begin{tabular}{|c|c|c|c|}
\hline Characteristic & $\begin{array}{l}\text { Converted } \\
(n=421)\end{array}$ & $\begin{array}{l}\text { Delayed converted } \\
\qquad(n=185)\end{array}$ & $\begin{array}{c}\text { Total } \\
(n=606)\end{array}$ \\
\hline & No. (\%) & No. (\%) & No. (\%) \\
\hline \multicolumn{4}{|l|}{ Sputum grading } \\
\hline Scanty & $118(96.7)$ & $4(3.2)$ & $122(20.1)$ \\
\hline $1+$ & $97(65.5)$ & $51(34.4)$ & $148(24.4)$ \\
\hline $2+$ & $92(63.0)$ & $54(36.9)$ & $146(24.1)$ \\
\hline $3^{+}$ & $111(60.3)$ & $73(39.6)$ & $184(30.4)$ \\
\hline $4^{+}$ & $3(50.0)$ & $3(50.0)$ & $6(1.0)$ \\
\hline \multicolumn{4}{|l|}{ Tuberculosis category } \\
\hline New & $375(74.5)$ & $128(25.4)$ & $503(83.0)$ \\
\hline Relapse & $35(43.7)$ & $45(56.2)$ & $80(13.2)$ \\
\hline Treatment after default & $8(42.1)$ & $11(57.8)$ & $19(3.1)$ \\
\hline Treatment after failure & $3(75.0)$ & $1(25.0)$ & $4(0.7)$ \\
\hline \multicolumn{4}{|l|}{ Treatment outcome } \\
\hline Cure & $283(67.5)$ & $136(32.4)$ & $419(69.1)$ \\
\hline Treatment default & $23(76.6)$ & $7(23.3)$ & $30(5.0)$ \\
\hline Died & $49(70.0)$ & $21(30.0)$ & $70(11.6)$ \\
\hline Transferred out & $66(75.8)$ & $21(24.1)$ & $87(14.4)$ \\
\hline \multicolumn{4}{|l|}{ Chest X-ray } \\
\hline Unknown status & $90(63.8)$ & $51(36.1)$ & $141(23.2)$ \\
\hline No lesions & $24(68.5)$ & $11(31.4)$ & $35(5.7)$ \\
\hline Far advanced lesions & $195(76.7)$ & $59(23.2)$ & $254(41.9)$ \\
\hline Moderate lesions & $64(60.3)$ & $42(39.6)$ & $106(17.4)$ \\
\hline Minimal lesions & $31(63.2)$ & $18(36.7)$ & $49(8.08)$ \\
\hline Other $^{a}$ & $17(80.9)$ & $4(19.2)$ & $21(3.4)$ \\
\hline \multicolumn{4}{|l|}{ Adverse drug reaction } \\
\hline Yes & $31(57.4)$ & $23(42.6)$ & $54(8.9)$ \\
\hline No & $391(70.8)$ & $161(29.2)$ & $552(91.1)$ \\
\hline \multicolumn{4}{|l|}{ Comorbidity } \\
\hline HIV & $21(58.3)$ & $15(41.6)$ & $36(5.9)$ \\
\hline Diabetes mellitus & $75(70.0)$ & $32(29.9)$ & $107(17.6)$ \\
\hline Hepatitis & $13(61.9)$ & $8(38.0)$ & $21(3.4)$ \\
\hline Other $^{b}$ & $39(75.0)$ & $13(25.0)$ & $45(7.4)$ \\
\hline None & $268(63.6)$ & $129(69.7)$ & $397(65.5)$ \\
\hline
\end{tabular}

HIV = human immunodeficiency virus.

Other $^{a}=$ pneumothorax, plural effusion, reticular nodular shadowing

Other $^{b}=$ hypertension, dyslipidaemia, chronic obstructive pulmonary disease, cancer, fractures.

Table 4 Multivariable analysis of factors associated with delayed sputum conversion

\begin{tabular}{|c|c|c|c|c|}
\hline Independent factor & $\beta$ & Standard error & Adjusted odds ratio (95\% CI) & P-value \\
\hline Moderate CXR lesions & 0.369 & 0.250 & $1.4(0.9-2.4)$ & 0.14 \\
\hline Age $\geq 50$ years & 0.640 & 0.200 & $1.8(1.3-2.8)$ & 0.001 \\
\hline Blue-collar work & 0.647 & 0.200 & $1.9(1.3-2.8)$ & 0.001 \\
\hline Smoking & 0.759 & 0.200 & $2.1(1.4-3.2)$ & $<0.001$ \\
\hline Sputum grading $2+$ & 0.905 & 0.248 & $2.4(1.5-4.6)$ & $<0.001$ \\
\hline Sputum grading $3^{+}$ & 0.981 & 0.234 & $2.6(1.7-4.2)$ & $<0.001$ \\
\hline Relapsed & 1.531 & 0.275 & $4.6(2.7-7.9)$ & $<0.001$ \\
\hline Treatment interrupted & 1.564 & 0.498 & $4.7(1.8-12.6)$ & 0.002 \\
\hline
\end{tabular}

CI = confidence interval.

CXR $=$ chest X-ray. 


\section{Acknowledgement}

We would like to thank the Director-General of Health Malaysia for his permission to publish this article and the health care professionals who facilitated us in conducting this study.

Funding: None.

Competing interests: None declared.

\section{Détermination des facteurs de risque associés à une conversion tardive des expectorations à la fin de la phase intensive du traitement chez les patients atteints de tuberculose}

\section{Résumé}

Contexte: Dans le domaine de la tuberculose pulmonaire (TBP), le taux de conversion des expectorations à deux mois est fréquemment utilisé pour évaluer les résultats du traitement et l'efficacité d'un programme de lutte contre la tuberculose.

Objectifs : La présente étude visait à estimer le taux de conversion tardive des expectorations et à explorer ses facteurs prédictifs à la fin de la phase intensive du traitement chez les patients atteints de TBP à frottis positif.

Méthodes : Une étude rétrospective sur trois ans a été menée dans l'hôpital public de Pulau Pinang de 2016 à 2018. Au cours de l'étude, un formulaire de collecte de données standardisé a été utilisé pour recueillir les données à partir des dossiers des patients. Des patients âgés de plus de 18 ans ont été recrutés. Une analyse de régression logistique multivariable a été utilisée pour identifier les variables indépendantes significatives associées à la conversion tardive des expectorations.

Résultats: Au total, 1128 patients atteints de TBP ont été enregistrés lors de leur consultation à la clinique de la tuberculose, 736 (65,2 \%) ont été diagnostiqués comme des patients atteints de TBP à frottis positif ; parmi eux, 606 patients $(82,3 \%$ ) avaient une conversion des expectorations à la fin de la phase intensive du traitement. Les facteurs suivants étaient significativement associés $(p<0,05)$ à la conversion tardive des expectorations : âge supérieur à 50 ans, emploi d'ouvrier, tabagisme, charge bacillaire élevée, rechute et interruption du traitement. Le taux de conversion tardive des expectorations à la fin de la phase intensive du traitement était de 30,6 \% .

Conclusion: Le taux de conversion des frottis d'expectoration dans la phase intensive du traitement était indépendamment associé à un classement élevé des frottis d'expectoration pendant le diagnostic, aux catégories d'interruption et de rechute du traitement, à l'âge avancé et aux professions ouvrières.

$$
\text { تحديد عوة بهاتي، عامر حياتي خان، سيد أزهار سيد سليطة بتأخر تحول البلغم في نهاية المرحلة مديحة لغاري، عرفان علي بن حيدة من العلاج بين مرضى السل }
$$

$$
\begin{aligned}
& \text { الخلفية: يستخدم معدل تحول البلغم بعد شهرين عادة مع مرض السل الرئوي، لتقييم مخرجات العلاج وفعالية برنامج مكافحة السل الرئوي. } \\
& \text { الأهداف: هدفت هذه الدر اسة إلى تقدير معدل تأخر تحول البلغم، وتحديد عوامل التنبؤ بحدوثه في نهاية المرحلة المكثفة من العلاج بين مرضى السل }
\end{aligned}
$$

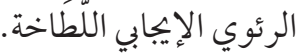

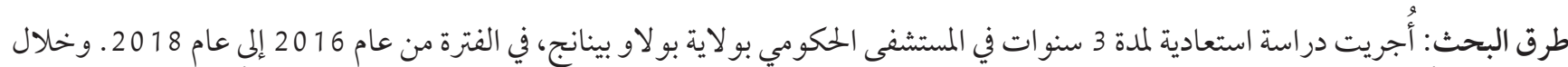

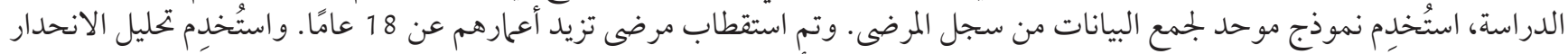

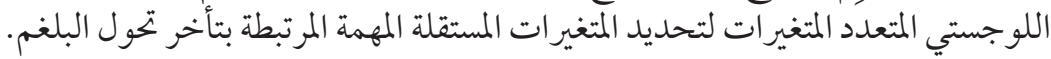

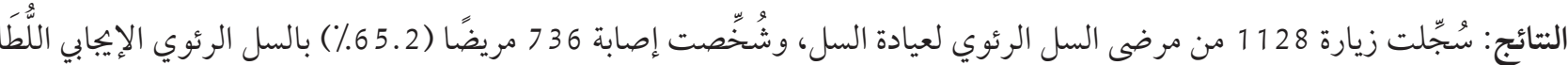

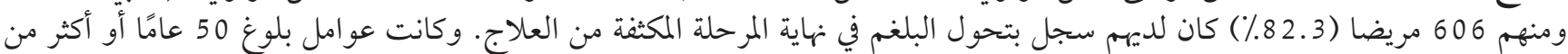

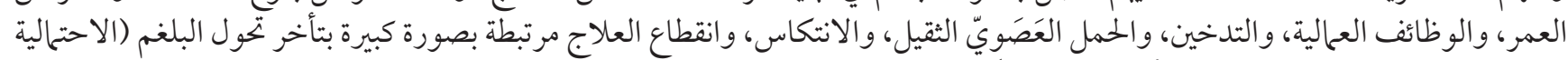

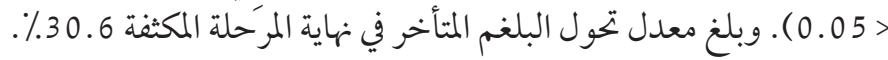

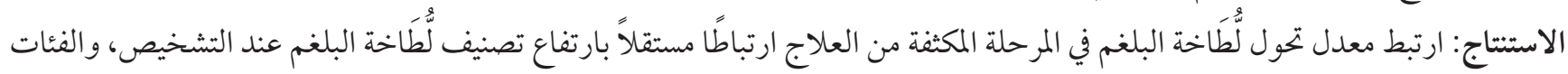

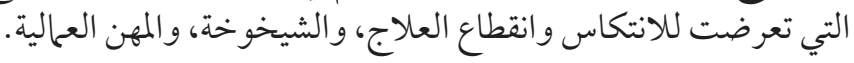




\section{References}

1. Mohd Anwar SA, Salmiah MS, Saliluddin SM, Lim PY Factors delaying sputum conversion in smear positive pulmonary tuberculosis: a systematic review. Int J Public Health Clin Sci. 2018;5(3):56-61. https://pdfs.semanticscholar.org/389c/d7836943670db29ff178ca7ce5ff53534960.pdf

2. Clinic practice guideline: management of tuberculosis, 3rd ed. Putrajaya, Malaysia: Ministry of Health; 2012. https://www.moh. gov.my/moh/attachments/8612.pdf

3. Kayigamba FR, Bakker MI, Mugisha V, Gasana M, van der Loeff MFS. Sputum completion and conversion rates after intensive phase of tuberculosis treatment: an assessment of the Rwandan control program. BMC Res Notes. 2012;5(1):357. doi:10.1186/17560500-5-357

4. Bouti K, Aharmim M, Marc K, Soualhi M, Zahraoui R, Benamor J, et al. Factors influencing sputum conversion among smear-positive pulmonary tuberculosis patients in Morocco. ISRN Pulmonol. 2013. doi:10.1155/2013/486507

5. Dominguez-Castellano A, Muniain M, Rodriguez-Bano J, Garcia M, Rios M, Galvez J, et al. Factors associated with time to sputum smear conversion in active pulmonary tuberculosis. Int J Tuberc Lung Dis. 2003;7(5):432-8. PMID:12757043

6. Gunda DW, Nkandala I, Kavishe GA, Kilonzo SB, Kabangila R, Mpondo BC. Prevalence and risk factors of delayed sputum conversion among patients treated for smear positive PTB in Northwestern rural Tanzania: a retrospective cohort study. J. Trop. Med. 2017; 2017:5352906. doi:10.1155/2017/5352906

7. Global tuberculosis reports 1997-2020. Geneva: World Health Organization; 2019. (https://www.who.int/tb/publications/global_report/en/, accessed 21 February 2021).

8. Population distribution and basic demographic characteristic report 2010 (Updated: 05/08/2011). Putrajaya, Malaysia: Department of Statistics; 2011. (https://www.dosm.gov.my/v1/index.php?r=column/ctwo\&menu_id=LopheU43NWJwRWVSZklWdzQ4TlhUUTo9, accessed 21 February 2021).

9. Atif M, Sulaiman SAS, Shafie AA, Ali I, Asif M. Treatment outcome of new smear positive pulmonary tuberculosis patients in Penang, Malaysia. BMC Infect Dis. 2014;14(1):399. doi:10.1186/1471-2334-14-399

10. Tok P, Salvaraji L, Rosli N, Badrul HAS. Impact of diabetes mellitus on the sputum conversion among new smear positive pulmonary tuberculosis patients in Johor Bahru, Malaysia. Johor Health J. 2016;12:1-9 (http://jknj.jknj.moh.gov.my/ejurnal/wp-content/ uploads/2017/03/Editted-A2-Dr-Peter-Tok-DM-and-TB-3.pdf, accessed 21 February 2021).

11. Shariff NM, Safian N. Diabetes mellitus and its influence on sputum smear positivity at the 2nd month of treatment among pulmonary tuberculosis patients in Kuala Lumpur, Malaysia: A case control study. Int J Mycobacteriol. 2015;4(4):323-9. doi:10.1016/j. ijmyco.2015.09.003

12. Gillani S, Sulaiman SAS, Ali JA. Clinical modalities and therapeutic outcomes; between ever-smokers versus never-smokers of tuberculosis patients in Penang, Malaysia. Eur J Gen Med. 2010;7(4):389-97. https://doi.org/10.29333/ejgm/82891

13. Treatment of tuberculosis: guidelines. Geneva: World Health Organization; 2010 (WHO/HTM/TB/2009.420; https://www.who. int/tb/publications/2010/9789241547833/en/, accessed 21 February 2021).

14. Djouma FN, Noubom M, Ateudjieu J, Donfack H. Delay in sputum smear conversion and outcomes of smear-positive tuberculosis patients: a retrospective cohort study in Bafoussam, Cameroon. BMC Infect Dis. 2015;15(1):139. doi:10.1186/s12879-015-0876-1

15. How SH, Kuan Y, Ng T, Fauzi A. Monitoring treatment response in sputum smear positive pulmonary tuberculosis patients: comparison of weight gain, sputum conversion and chest radiograph. Malays J Pathol. 2014;36(2):91. PMID: 25194531

16. Diktanas S, Vasiliauskiene E, Polubenko K, Danila E, Celedinaite I, Boreikaite E, et al. Factors associated with persistent sputum positivity at the end of the second month of tuberculosis treatment in Lithuania. Tuberc Respir Dis. 2018;81(3):233-40. doi:10.4046/trd.2017.0096

17. Ambreen A, Jamil M, ur Rahman MA, Mustafa T. Viable Mycobacterium tuberculosis in sputum after pulmonary tuberculosis cure. BMC Infect Dis. 2019;19(1):923. doi:10.1186/s12879-019-4561-7

18. Kuaban C, Bame R, Mouangue L, Djella S, Yomgni C. Non-conversion of sputum smears in new smear positive pulmonary tuberculosis patients in Yaoundé, Cameroon. East Afr Med J. 2009;86(5):219-25. doi:10.4314/eamj.v86i5.54192

19. Ukwaja KN, Oshi DC, Oshi SN, Alobu I. Profile and treatment outcome of smear-positive TB patients who failed to smear convert after 2 months of treatment in Nigeria. Trans R Soc Trop Med Hyg. 2014;108(7):431-8. doi:10.1093/trstmh/truo70.

20. Lee J, Lee BJ, Yoon HI, Lee CT, Lee JH. Influence of previous tuberculosis treatment history on acid-fast bacilli smear and culture conversion. Int J Tuberc Lung Dis. 2012;16(10):1344-8. doi: 10.5588/ijtld.12.0113

21. Mota PC, Carvalho A, Valente I, Braga R, Duarte R. Predictors of delayed sputum smear and culture conversion among a Portuguese population with pulmonary tuberculosis. Rev Port Pneumol. 2012;18(2):72-9. doi:10.1016/j.rppneu.2011.12.005

22. Santha T, Garg R, Frieden T, Chandrasekaran V, Subramani R, Gopi P, et al. Risk factors associated with default, failure and death among tuberculosis patients treated in a DOTS programme in Tiruvallur District, South India, 2000. Int J Tuberc Lung Dis. 2002;6(9):780-8. PMID:12234133

23. Babalik A, Kiziltas S, Arda H, Oruc K, Celintas G, Calalettin H. Factors affecting smear conversion in tuberculosis management. Med Sci. 2012;1(4):351-62. doi:10.5455/medscience.2012.01.8036

24. Maciel E, Brioschi A, Peres R, Guidoni L, Ribeiro F, Hadad D, et al. Smoking and 2-month culture conversion during anti-tuberculosis treatment. Int J Tuberc Lung Dis. 2013;17(2):225-8. doi:10.5588/ijtld.12.0426 
25. Gupta PC, Pednekar MS, Parkin D, Sankaranarayanan R. Tobacco associated mortality in Mumbai (Bombay) India. Results of the Bombay cohort study. Int. J. Epidemiol. 2005;34(6):1395-402. doi:10.1093/ije/dyi196

26. Wang J-Y, Hsueh P, Jan I, Lee L, Liaw Y-S, Yang P, et al. The effect of smoking on tuberculosis: different patterns and poorer outcomes. Int J Tuberc Lung Dis. 2007;11(2):143-9. https://doi.org/10.1371/journal.pone.0156677

27. Slim A, Daghfous H, Mansour AB, Kchouk H, Ezzaouia A, Saad SB, et al. Predictive factors of delayed sputum conversion in pulmonary tuberculosis. Eur Resp J. 21 November 2019;54(Suppl. 63):PA4616. doi:10.1183/13993003.congress-2019.PA4616

28. Singla R, Bharty SK, Gupta UA, Khayyam KU, Vohra V, Singla N, et al. Sputum smear positivity at two months in previously untreated pulmonary tuberculosis patients. Int J Mycobacteriol. 2013;2(4):199-205. doi:10.1016/j.ijmyco.2013.08.002

29. Singla R, Srinath D, Gupta S, Visalakshi P, Khalid U, Singla N, et al. Risk factors for new pulmonary tuberculosis patients failing treatment under the Revised National Tuberculosis Control Programme, India. Int J Tuberc Lung Dis. 2009;13(4):521-6. PMID:19335960 